\title{
Biochemical Study On the Effect of Morin and Rutin in amelioration of Titanium dioxide Nanoparticle Toxicity in rat liver
}

\author{
Mohamed H. Sherif' ${ }^{1}$ Mohamed M. Hussein ${ }^{2}$, Reham S. Eid ${ }^{3}$ and Al-Shimaa M. Abas³ \\ ${ }^{1}$ Chemistry Department, Faculty of Science, Zagazig University, Egypt \\ ${ }^{2}$ Biochemistry Division, Chemistry Department, Faculty of Veterinary medicine, Zagazig University, Egypt \\ ${ }^{3}$ Biochemistry Division, Chemistry Department, Faculty of Science, Zagazig University, Egypt
}

\begin{tabular}{l}
\hline A R T I C L E I N F O \\
\hline Keywords: \\
Titanium dioxide nanoparticles; Morin; \\
Rutin; Antioxidant; hepatotoxicity.
\end{tabular}

Rutin; Antioxidant; hepatotoxicity.

\begin{abstract}
A B S T RACT
Background: Titanium dioxide nanoparticles (TiO2 NPs) were healthy well-known as a photocatalyst and it was extensively utilized for photocatalysed corrosion, sensor essentials, water distillation and had numerous other submission. Also, in food industry. However they also had poisonous result on animals uncovered to them. Objectives: we examined the probable ameliorative result for the two flavonoids morin and rutin which had apotent antioxidant activity, against $\mathrm{TiO} 2$ nanoparticles-induced toxicities in rat liver. Materials and methods: Albino rats ( $\mathrm{n}=70$, weight $150-200 \mathrm{~g}$ ) were divided into seven groups. Group (G1) (control), G2 (treated with morin $30 \mathrm{mg} / \mathrm{kg}$ ), G3 (treated with rutin $80 \mathrm{mg} / \mathrm{kg}$ ), G4 (toxic group that administrated orally with titanium dioxide nanoparticles $100 \mathrm{mg} / \mathrm{kg}$ ), G5 (TiO2 NPs+ morin), G6 (TiO2 NPs + rutin), G7 (TiO2 NPs + morin + rutin). The evaluated parameters included liver function markers, some minerals and electrolytes, antioxidant (superoxide dismutase SOD, catalase CAT and glutathione GSH) and oxidative stress malondialdehyde (MDA) biomarkers in addition to DNA fragmentation and histopathological examination of liver tissues. Results: These experimental study showed that a significant increase of serum ALT, AST, ALP activities. Also, serum potassium $(\mathrm{K})$ and phosphorous $(\mathrm{P})$ levels, hepatic MDA content, comet, tail length, DNA in tail and tail moment of DNA fragmentation were detected in TiO2 NPs (G4) group indicating liver damage which compared with control group (G1) but this parameters decreased significantly in morin (G5) or rutin (G6) when compared with toxic group (G4), in combination group (TiO2 NPs+ morin+ rutin) (G7) succeeded to decrease significantly in this parameters and returns to (G1). Also, our results showed that a significant decrease in total protein, albumin, sodium $(\mathrm{Na})$, calcium $(\mathrm{Ca})$ levels, glutathione (GSH) level, superoxide dismutase (SOD) and catalase (CAT) activities in toxic groups (G4) but succeeded to increase significantly in this parameters in G5, G6 and G7 in compared with control group and restore it. Conclusion: TiO2NPs oral
\end{abstract}


administration induced toxic effects and DNA damage in the liver that may be attributable to oxidative stress.Also, administration of morin and/or rutin with TiO2NPs offers protection against their damaging effect.

\section{Introduction:}

Nanotechnology was measured as a extraordinarily confident knowledge in the field of molecular science that might use in therapeutic, cultivation industrial, manufacturing and armed forces part $(\mathbf{1}, \mathbf{2})$. The titanium dioxide nanoparticles $\left(\mathrm{TiO}_{2} \mathrm{NPs}\right)$ have been utilized in paints, plastics, papers, foundation and healthy skin yield like sunscreen cream as they extend out perceptible light less than $\mathrm{TiO}_{2}$ dye, while still given that UV safeguard and source less skin pain than other UV fascinating chemicals $(3,4)$. Although these NPs had anticancer properities against a number of cancer cells like creature hepatoma cells (5), they could likewise harm the usual in good physical shape cells after exposure via oral or respiratory route (6). Morin was one of the physically occurring bioflavonoids, formerly isolated from component of the Moraceae family (7), and in enormous quantities found in divergent herbs and fruits like onion, seed weeds, mill, fig, almond, red wine and osage orange $(\mathbf{8 ,} 9)$. Some pharmacological considered exposed that morin had antioxidant, antiinflammatory, chemoprotective, anticancer and anti-promotion material goods (10). Rutin, a citrus flavonoid glycoside current principally in buckwheat, also had antioxidant, antiallergic, anti-inflammatory, antiangiogenic, antiviral assets (11). It was utilized in a lot of pharmaceutical arrangements as an adjuvant for anticancer, antidiarrhoeal and myocardial defensive drugs (12).

The principle of the current learn was to examine the likely defensive result of actually happening antioxidants (morin and rutin) in titanium dioxide nanoparticles $\left(\mathrm{TiO}_{2}\right.$ NPs $)$ stimulated liver toxicity in rats via resolve of a few biochemical parameters in bloodmlike liver function tests and some minerals. Also, liver tissue of rats like oxidative stress and antioxidant markers as well as DNA damage and histopathological examination of liver tissue for results confirmation.

\section{Materials and Methods:}

\section{Chemicals}

Both morin and rutin were purchased from Sigma-Aldrich Chemical Co. (St Louis, Missouri, USA).

Full characterized mixture of rutile and anatase $\mathrm{TiO}_{2}$ NPs purchased from Sigma-Aldrich chemicals Co. (St, Louis, MO 63103, USA).

All chemicals were dissolved in distilled water.

\section{Experimental design}

A complete number of 70 adult male albino rats were housed in metal cages. Rats were put at steady ecological and dietary conditions during the time of experiment. The animals were left for two weeks (14 day) for acclimatization before start of the examination. The experimental study was approved by the Animal Ethical Committee of Faculty of Veterinary Medicine, Zagazig, and was in accordance with its rules.

The dose was chosen by WHO in 1969 . That $\mathrm{LD}_{50}$ of $\mathrm{TiO}_{2}$ for rats is over than $12,000 \mathrm{mg} / \mathrm{kg}$ body weight (b.w) after orally administration (13). The dose of $100 \mathrm{mg} / \mathrm{kg}$ (b.w) of $\mathrm{TiO}_{2}$ NPs was chosen for the present study and orally administrated to rats every day. Animals were separated into seven groups (10 rats per group): 
Group 1 (G1): Rats were orally administrated with normal saline each day for 4 weeks.

Group (2): Rats were orally administrated with morin at a dose of (30 $\mathrm{mg} / \mathrm{kg}$ ) for 4 weeks daily (14).

Group (3): Rats were orally administrated with rutin $(80 \mathrm{mg} / \mathrm{kg}$ b.wt/day) daily for 4 weeks (15).

Group (4): Rats were treated orally with $\mathrm{TiO}_{2}$ NPs (100 mg/kg b.wt/day) for four weeks (16).

Group (5): Rats were treated orally with $\mathrm{TiO}_{2}$ NPs (100 mg/kg b.wt/day) followed by morin (30 mg/kg b.wt/day) for four weeks.

Group (6): Rats were orally administrated $\mathrm{TiO}_{2}$ NPs $(100 \mathrm{mg} / \mathrm{kg}$ b.wt/day) followed by rutin $(80 \mathrm{mg} / \mathrm{kg}$ b.wt/day) for four weeks.

G (7): Rats were treated with $\mathrm{TiO}_{2}$ NPs (100 $\mathrm{mg} / \mathrm{kg} \mathrm{b.wt/day)} \mathrm{for} \mathrm{four} \mathrm{weeks}$ followed by morin $(30 \mathrm{mg} / \mathrm{kg} \mathrm{b} . w \mathrm{w} /$ day $)$ and rutin $(80 \mathrm{mg} / \mathrm{kg} \mathrm{b.wt/day)} \mathrm{according}$ to the same doses and routes of previous groups for four weeks.

\section{Sampling}

At the end of experimental period (4 weeks) blood samples were collected from all animals of all studied groups before killed them by puncturing reteroorbital venous plexus located at the media canthus of the eye in dry, clean wserman tubes and incubated for $10 \mathrm{~min}$ in water bath at $37^{\circ} \mathrm{c}$ fro clotting then centrifuged at 3000 r.p.m for 15 minutes and then serum collected in Eppendrof's tubes using automatic micropipettes for measurement serum (ALT, AST, ALP, total protein, albumin, total bilirubin, direct bilirubin) and minerals (calcium $\mathrm{Ca}$, phosphorous $\mathrm{P}$, sodium $\mathrm{Na}$, potassium $\mathrm{K})$

\section{Liver tissue specimens}

Rats were killed by cervical decapitation and livers were dissected out from all animal groups then divided into 3 parts.

- For biochemical analysis (antioxidant and oxidative stress biomarker), liver samples rinsed in cold physiological isotonic saline $(0.9 \% \quad \mathrm{NaCl})$ to remove contaminated blood. To obtained $10 \%$ homogenate; $1 \mathrm{gm}$ of tissue sample was sliced and homogenized in $10 \mathrm{ml}$ physiological saline using electric homogenizer. The homogenate was centrifuged at 3000 r.p.m for $15 \mathrm{~min}$. The clear supernatant was obtained for determination of MDA, GSH concentration, SOD, catalase activities.

- For determination of DNA damage using comet assay to follow up changes in comet \%, Tail Length (px), \%DNA in Tail, Tail Moment. liver tissues were taken from rats and put in saline contained $(1 \mathrm{ml})$ eppendrof's tubes then put in $-80^{\circ} \mathrm{c}$ deep freezer to make snap-freezing of tissue and minimize action of endogenous RNase and small parts of liver were cut then put them in Eppendrof's tube.

- For histopathological examination, where small pieces of liver were cut and fixed in $10 \%$ neutral buffered formalin solution.

\section{Biochemical Analysis}

Serum activity of ALT \& AST were determined according to the method (17) and serum ALP was determined according to the method (18) using a commercial kit supplied by ELITech. Total Protein was determined according to the method (19) using commercial kit supplied by Diamond, Egypt, albumin was determined according to the method (20) using commercial kit supplied by Spectrum, Spain, Egypt and Bilirubin was determined according to method of (21) using commercial kit supplied by Diamond, Egypt. 
Serum calcium and Phosphorous were determined (22), potassium (23), sodium (24) were determined according to methods described and used commercial kit supplied by SPINREACT, Obour city industrial area.

Malondialdehyde level was determined spectrophotometrically (25). Superoxide dismutase (26) and Catalase (27) were determined using commercially available kits (Bio-diagnostic, Egypt).

\section{DNA Fragmentation:}

The single cell gel electrophoresis (Comet assay):

The comet assay was performed in Animal Reproductive Research Institute (ARRI) of Agricultural Research Centre of Ministry of Agriculture and Land Reclamation, Cairo, Egypt, according to the method (28).

Comet Assay is a technique for quantitating DNA damage and repair in eukaryotic cells and some prokaryotic cells.

In this technique cells were embedded in low melting point agarose (LMP), plated onto microscope slides, were destroyed with detergent and high salt to form immobilized nucleoids contained supercoiled loops of DNA linked to the nuclear matrix. Single or double stranded breaks in DNA, by action of damaging agents or conditions, may cause to loss of supercoiling and DNA fragments freed from the nuclear matrix. When put in an electrophoretic field, these uncoiled strands and fragments of DNA migrated across the agarose and extend toward the anode. Cells with DNA break down present a comet like appearance, with a nucleoid head and a streaming tail. Fluorescent intensities abbeared in the structures are proportionate to the quantities of DNA present. Cells without DNA damage, showed up essentially as roughly round fluorescent nucleoid heads with no tail.
Briefly, $75 \mu$ of each treated aliquot was mixed with low melting point agarose (LMP) at $0.7 \%$ and was put on glass slides treated with normal melting agarose $(0.5 \%)$ at $1 \%$. After $30 \mathrm{~min}$, another layer low melting agarose (LMP, $0.7 \%$ ) was added. The slides were treated with lysis buffer $(\mathrm{NaCl} 2.5 \mathrm{M}$, Na2EDTA $0.1 \mathrm{M}$, Tris - Base $0.4 \mathrm{M}$, TRITON $\mathrm{X}-100 \quad 1 \%$, dimethyl sulfoxide (DMSO) 10\%, pH 10) and were enzymatically digested with proteinase $\mathrm{K}(0.5 \mu \mathrm{g} / \mathrm{L})$. Then, the slides, previously washed with a neutralizing solution, were put on alkaline unwinding for 10min in a basic solution $(\mathrm{NaOH} 10$ $\mathrm{N}$, EDTA $200 \mathrm{mM}, \mathrm{pH}$ 12.1) and experienced electrophoresis $(25 \mathrm{~V}, 300$ $\mathrm{mA}, 20 \mathrm{~min}$ ). Finally, the slides were fixed in cold methanol, stained with ethidium bromide and observed by a fluorescence microscope with $\times 60$ magnification (Nikon Eclipse E-600, Nikon Corporation Tokyo, Japan) equipped with band pass (BP) 515-560 $\mathrm{nm}$ and long pass (LP) $580 \mathrm{~nm}$ filters. The pictures were obtained by methods for the Komet program version 6.0.0 (Andor Technology, Belfast, United Kingdom). The parameter considered was level of damaged DNA present in the comet tail (\%Tail DNA).

\section{Histopathological examination}

Samples were then immersed with molted paraffin wax, then embedded and blocked out. Paraffin sections (4-5 um) were stained with hematoxylin and eosin, (29).

\section{Statistical analysis}

All the data were expressed as means \pm SE. The statistical significance was evaluated by one-way analysis of variance (ANOVA) using SPSS, 18.0 software, 2011 and individual comparisons were obtained by Duncan's multiple range test (DMRT). Values were considered statistically significant when $(\mathrm{p}<0.05)(\mathbf{3 0})$. 
Results:

Effect of morin and/or rutin administration on liver function tests in $\mathrm{TiO}_{2} \mathrm{NPs}$ intoxicated rats.

Our obtained results revealed that administration of $\mathrm{TiO}_{2}$ NPs (G4) led to significant increase of serum ALT, AST, ALP activities and total bilirubin level in compared to control groups (G1-G3) (Table 1). In contrast, administration of morin (G5) and rutin (G6) each alone or in combination (G7) led to significant decrease of these liver markers to a limit comparable to that of the control groups (G1-G3) (Table 1).

The present study also showed that oral administration of $\mathrm{TiO}_{2} \mathrm{NPs}(\mathrm{G} 4)$ resulted in a significant decrease in serum levels of total protein and albumin as compared to control groups (G1-G3) (Table 1).

This toxic effect was reversed after giving morin and/or rutin. by increased total protein and albumin level in serum of treated rats.

\section{Effect of TiO2 NPs administration on} serum minerals and possible protective effect of morin and/or rutin

A significant increase in levels of serum $\mathrm{K}$ and $\mathrm{P}$ and significant decrease in $\mathrm{Na}^{+}$ and $\mathrm{Ca}$ serum levels were observed in $\mathrm{TiO}_{2} \mathrm{NPs}$-treated group (G4) as compared to the controls (G1-G3). Combined administration of morin and/or rutin with $\mathrm{TiO}_{2} \mathrm{NPs}$ caused a significant decrease in $\mathrm{K}^{+}$and phosphorous $(\mathrm{P})$ levels and a significant increase in $\mathrm{Na}^{+}$and $\mathrm{Ca}$ levels as compared to G4 Table 2).

Effect of morin and/ or rutin administration on liver MDA and GSH concentrations, SOD and CAT activities in $\mathrm{TiO}_{2}$ NPs-treated rats

In the present study, rats treated with $\mathrm{TiO}_{2}$ NPs exhibited a significant increase in liver content of the lipid peroxidation marker, MDA and a significant decrease in GSH level and the antioxidant activities of SOD and CAT as compared to control groups (G1-G3). Treatment with morin and/or rutin significantly attenuated lipid peroxidation and restored values of antioxidant GSH, SOD AND CAT in comparable to that of control groups (Table 3 ).

Effect of morin and/ or rutin administration on DNA fragmentation induced by $\mathrm{TiO}_{2}$ NPs.

Comet assay results revealed a significant increase in DNA percentage damage, tail length, tail moment in liver tissues nuclei of $\mathrm{TiO}_{2}$ NPs-treated group as compared to the three control groups. On the other hand, administration of morin and/or rutin along with $\mathrm{TiO}_{2} \mathrm{NPs}$ significantly lowered DNA damage as revealed by reduction in the level of DNA tail percentage damage, tail length, and tail moment (Table 4) (Figure 1\&2).

Effect of morin and/ or rutin administration on liver histology

Figure 4 showed the histopathological changes in rats liver tissues. In control groups (G1-G3), liver sections showed normal hepatic parenchyma with preserved lobular pattern, portal triads structures, vascular tree, kupffer cells and stromal component (Fig.3A-C) (X300). In contrast, $\mathrm{TiO}_{2}$ NPs-treated group (G4) showed hydropic degeneration in most hepatic parenchyma (open arrow) with congested hepatic blood vessels (arrowhead), besides hemorrhagic area in some examined sections (curved arrow) (Fig.3D, E) (X300). On the other hand, morin-treated group (G5) showed slight vacuolar degeneration in few areas of hepatic parenchyma (open arrow, Fig.3F) (X300), while rutintreated group (G6) exhibited normal hepatic parenchyma with slight round mononuclear cells infiltration in portal area (open arrow, Fig.3G) (X300). Notably, the co-treated group showed normal hepatic parenchyma with round 
mononuclear cells infiltration in some examined sections (closed arrow, Fig.3H) (X300).

\section{Discussion}

Nanoparticles differ from that of the fine particles as regard physicochemical properties. They have smaller size, large number of atoms on their surface and different surface characteristics, as level of energy. These differences attract more attentions to study adverse effects of nanoparticles (31). Titanium dioxide nanoparticles (TiO2 NPs) were highly applied in high number of fields as resistance to corrosion, few cost, whitening agent, in cosmetics, pharmacy and medicine. Their tremendous use is because of their biocompatibility, photo catalysis and ease of obtaining in nano sizes (32).

Presentation to $\mathrm{TiO} 2$ NPs can be happened by all routes, including inhalation, ingestion, diverse skin applications, and injections. After absorption, they were appropriated to various organs of the body as kidneys, liver, lungs, brain, and lymphatic organs produced toxic effects on these organs (33).

Oral administration is related to when evaluated the danger of food additives, pharmacological parameters ADME (absorption, distribution, metabolism, and excretion) are frequently done with IP administration as the biochemical mode of presentation. So we have settled on this route of administration as possible utilized in toxicological studies performed on $\mathrm{TiO} 2$ NPs (33). The liver is the huge distribution organ due to its high blood irrigation and the phagocytosis of NPs by Kupffer cells (33).

The aim of this study was investigate hepotential toxicity of titanium dioxide nanoparticles and to evaluate the possible role of morin and rutin in amelioration these toxic effects.
Our obtained results revealed that administration of $\mathrm{TiO}_{2} \mathrm{NPs}(\mathrm{G} 4)$ led to significant increase of serum ALT, AST, ALP activities and total bilirubin level in compared to control groups (G1-G3) (Table 1). This indicates liver damage in G4 rats and suggests possible hepatic toxicity induced by $\mathrm{TiO}_{2}$ NPs. Most nanoparticles tend to accumulate in the liver (34) and lead to liver damage or injury This in agreement with who reported that high doses of $\mathrm{TiO}_{2} \mathrm{NPs}$ significantly increased the same parameters (35-37). In contrast, administration of morin (G5) and rutin (G6) each alone or in combination (G7) led to significant decrease of these liver damage markers to a limit comparable to that of the control groups (G1-G3) (Table 1). This suggests a possible ameliorative effect to these two flavonoids against liver toxicity induced by $\mathrm{TiO}_{2} \mathrm{NPs}$. Morin had been appeared to diminish liver harm, prevent the escape of liver enzymes through keeping up of cell membranes integrity $(\mathbf{3 8}, \mathbf{3 9})$.

The present study also showed that oral administration of $\mathrm{TiO}_{2} \mathrm{NPs}(\mathrm{G} 4)$ resulted in a significant decrease in serum levels of total protein and albumin as compared to control groups (G1-G3) (Table 1).

This also indicates liver damage and loss of function. Again this toxic effect was reversed after giving morin and/or rutin. Similarly, rutin improved the liver damage as revealed by reduction of total protein and albumin level in serum of intoxicated rats (40).

A significant increase in $\mathrm{K}^{+}$and phosphorous $(\mathrm{Ph})$ serum levels and a significant decrease in $\mathrm{Na}^{+}$and $\mathrm{Ca}$ serum levels were observed in $\mathrm{TiO}_{2} \mathrm{NPs}$-treated group (G4) as compared to the controls (G1-G3, Table 2). Combined administration of morin and/or rutin with $\mathrm{TiO}_{2} \mathrm{NPs}$ caused a significant decrease in $\mathrm{K}^{+}$and phosphorous $(\mathrm{Ph})$ levels and a significant increase in $\mathrm{Na}^{+}$and $\mathrm{Ca}$ levels as compared to G4. In support to our 
findings, (41) reported that $\mathrm{TiO}_{2}$ NPs showed huge diminishing in $\mathrm{Na}$, KATPase activity and a significant increase in Ca-ATPase activity. Moreover, (42) also found that morin can significantly increase $\mathrm{Na}$ and decrease $\mathrm{K}$. On the other hand, rutin-treated groups displayed a critical expanded $\mathrm{Na}$ concentration after doxorubicin treatment (43).

In the present study, rats treated by $\mathrm{TiO}_{2}$ NPs caused a significant increase in liver content of the lipid peroxidation marker, MDA and a significant decrease in GSH level and the antioxidant activities of SOD and CAT as compared to control groups (G1-G3) (Table 3). In consistent with our data, several previous studies on toxicity of $\mathrm{TiO}_{2} \mathrm{NPs}$ showed the same results were found the production of an ROS following introduction to $\mathrm{TiO} 2$ NPs was because of the decrease of SOD activity and GSH-PX and to the increase of MDA levels. Mice which orally administrated to $\mathrm{TiO} 2 \mathrm{NPs}$ observed upregulated 8-hydroxyl deoxyguanosine (8-OHdG) level and DNA damage in the liver. In addition to the ROS production increased, along with the inhibition of antioxidants levels. MDA values were increased in liver and kidneys tissues which may led to cell apoptosis. Study showed that the level of ROS in liver and kidney tissur cells of mice for increased Nrf2. Nrf2 is the master regulator for expression of different antioxidant genes $(\mathbf{4 4}, \mathbf{4 5})$. Moreover, Similar to our outcomes, $(\mathbf{3 8}, \mathbf{3 9})$ found that treatment with morin significantly $(p<0.05)$ decreased MDA and restored levels of antioxidant enzyme glutathione to levels close to that of control groups. Similarly, administration of rutin prompted a critical rise in SOD, CAT activities and GSH level and a significant reduction in MDA level (46).
Comet assay results revealed a significant increase in DNA percentage damage, tail length, tail moment in liver tissues nuclei of $\mathrm{TiO}_{2}$ NPs-treated group as compared to the three control groups ((Table 4, Figures 1\&2). On the other hand, administration of morin and/or rutin along with $\mathrm{TiO}_{2}$ NPs significantly lowered DNA damage as revealed by reduction in the level of DNA tail percentage damage, tail length, and tail moment. These results are in agreement with (44) who showed $\mathrm{TiO}_{2} \quad \mathrm{NPs}$ exposure produced DNA damage in liver cells. Other studies also revealed that $\mathrm{TiO}_{2}$ NPs can cause mutation statistically significant loss of sperm DNA integrity after half hour of exposure by comet assay (47). The DNA damage might be because of point mutations and/or DNA rearrangements; loss of bands. The disappearance of bands may be due to the formation of DNA adducts or double - strand breaks morever. Those molecular events were related to increased ROS formation (48). In contrast, some others researchers did not confirm the genotoxic effects of $\mathrm{TiO}_{2}$ NPs (49-51). On the other hand, (40) likewise found that administration of rutin significantly decreased DNA damage in a dose dependent way in rat treated with $\left(\mathrm{KBrO}_{3}\right)$ as compared to the control group.

Figure 3 showed the histopathological changes in rats liver tissues. In control groups (G1-G3), liver sections showed normal hepatic parenchyma with preserved lobular pattern, portal triads structures, vascular tree, kupffer cells and stromal component (Fig.4A-C) (X300). In contrast, $\mathrm{TiO}_{2}$ NPs-treated group (G4) showed hydropic degeneration in most hepatic parenchyma (open arrow) with congested hepatic blood vessels (arrowhead), besides hemorrhagic area in some examined sections (curved arrow) (Fig.4D, E) (X300). On the other hand, morin-treated group (G5) 
showed slight vacuolar degeneration in few areas of hepatic parenchyma (open arrow, Fig.4F) (X300), while rutintreated group (G6) exhibited normal hepatic parenchyma with slight round mononuclear cells infiltration in portal area (open arrow, Fig.4G) (X300). Notably, the co-treated group showed normal hepatic parenchyma with round mononuclear cells infiltration in some examined sections (closed arrow, Fig.4H) (X300).

Similar to our findings (44). Also, showed that $\mathrm{TiO}_{2}$ NPs caused congestion and lymphocytic aggregation. In addition to that, (52) documented that $\mathrm{TiO}_{2}$ NPs also caused fibrosis around the central vein where $\mathrm{TiO}_{2}$ NPs always aggregated. In opposite, administration of morin reduced the severity of the harm in the hepatocytes and preserves the structural integrity of the liver by virtue of its antioxidant properties (38). Similarly, treatment of rutin showed a significant restoration of the hepatic lesions and architecture of the liver following intoxication (53).

\section{Conclusion}

Morin and/or rutin could improve the damaged liver tissues and the associated disrupted function that induced by $\mathrm{TiO}_{2}$ NPs toxicity. The results suggest that morin and rutin may be appropriate for clinical application in the treatment of liver disorders induced by $\mathrm{TiO}_{2} \mathrm{NPs}$ toxicity and the use of $\mathrm{TiO}_{2} \mathrm{NPs}$ should be conjugated with flavonoids to overcome their hepatotoxic effect.

\section{References:}

1. Robertson T.A, Sanchez W.Y, Roberts M.S. (2010): Are commercially available nanoparticles safe when applied to the skin? J Biomed Nanotechnol, 6:452-468.

2. Kisin E.R, Murray A.R, Keane M.J, Shi X.C, Schwegler-Berry D, Gorelik O, Arepalli S,
Castranova V, Wallace W.E, Kagan V.E, Shvedova A.A. (2007): Single-walled carbon nanotubes: geno- and cytotoxic effects in lung fibroblast V79 cells. J Toxicol Environ Health A, 70:2071-2079.

3. Brunet L, Lyon D.Y, Hotze E.M, Alvarez P.J, Wiesner M.R. (2009): Comparative photoactivity and antibacterial properties of C-60 fullerenes and titanium dioxide nanoparticles. Environ Sci Technol. 43: 43554360.

4. Winkler, Jochen. (2003): Titanium Dioxide. Hannover: Vincentz Network. pp. 5.ISBN 387870-148-9.

5. Wang L, Mao J, Zhang G.H, Tu M.J. (2007): Nano-ceriumelement-doped titanium dioxide induces apoptosis of Bel 7402 human hepatoma cells in the presence of visible light. World J Gastroenterol 13:4011-4014.

6. Cui Y, Gong X, Duan Y, Li N, Hu R, Liu H et al. (2010): Hepatocyte apoptosis and its molecular mechanisms in mice caused by titanium dioxide nanoparticles. J Hazard Mater 183:874-880.

7. Khaki A, Fathiazad F, Nouri M, Khaki A.F (2010): Beneficial effects of quercetin on sperm parameters in streptozotocininduced diabetic male rats. Phytother Res. 24: 12851291.

8. Sreedharan $\mathbf{V}$, Venkatachalam K.K, Namasivayam N (2009): Effect of morin on tissue lipid peroxidation and antioxidant status in $1, \quad 2$ dimethylhydrazineinduced 
experimental colon carcinogenesis. Invest. New Drugs. 27: 21-30.

9. Nandhakumar R, Salini $\mathbf{K}$, Devaraj S.N. (2012): Morin augments anticarcinogenic andantiproliferative efficacy against 7, 12-dimethylbenz (a)anthracene induced experimental mammary carcinogenesis. Mol. Cell. Biochem., 364: 79-92.

10. Kuo H.M, Chang L.S, Lin Y.L, Lu H.F, Yang J.S, Lee J.H, Chung J.G. (2007): Morin inhibits the growth of human leukemia HL-60 cells via cell cycle arrest and induction of apoptosis through mitochondria dependent pathway. Anticancer

\section{Guruvayoorappan C, Kuttan}

G. (2007): Antiangiogenic effect of rutin and its regulatory effect on the production of VEGF,IL$1 \mathrm{~B}$ and TNF-a in tumor associated macrophages .J.BoilSci .,7:1511-1519.

12. Pozin V.M, Skuratovskaia S.G, Pocheptsova G.A. (1996): Changes in the vascular wall and ischemic damages to the myocardium in reversible episodes of heart muscle ischemia. Fiziologicheskii Zhurnal, 42:10-16.

\section{World Health Organization} (WHO). (1969): FAO Nutrition Meetings Report Series No. 46A: Toxicological evaluation of some food colours, emulsifiers, stabilizers, anti-caking agents and certain other substances. WHO/ FOOD ADD/70.36.
14. Alkhamees O.A. (2013): Morin a flavoniod exerts antioxidant potential in streptozotocininduced hepatotoxicity. British Journal of pharmacology and Toxicology 4(1): 10-17; ISSN:2044-2459; e- ISSN: 20442467.

15. Mirani N, Nagma, Ashraf J, Siddique J, Rub A. (2012): Protective effect of rutin cadmium induced hepatotoxicity in swiss albino mice. Journal of Pharmacology and Toxicology, ISSN 1816-496X; DOI: 103923/Jpt.

16. Vasantharaja D, Ramalingam V, Reddy G.M. (2014): Oral toxic exposure of titanium dioxide nanoparticles on serum biochemical changes in adult male wisters rats. Nanomedicine Journal, Online ISSN 2322-5904.

17. Breuer G. (1996): Report on the symposium (drug effects in clinical chemistry methods) eur $g$ clin chem. Clin biochem. ; 34:385-386.

18. Moss D.W. (1982): Alkaline Phosphatase isoenzymes. Clin. Chem. 28:2007-2016.

19. Yatzidis H.L. (1987): J. Clin., Chem., 23/908.

20. Rodkey F.L. (1974): Clin., Chem: Acta 53:109-115.

21. Kaplan A et al. (1984): Bilirubin. Clin Chem The C.V.Mosby Co. St Louis. Toronto. Princeton 12381241,436 and 650. 
22. Farrell E.C, Calcium. Kaplan A et al. (1984): Clin Chem The C.V. Mosby Co. St Louis. Toronto. Princeton; 1051-1255 and 418.

23. Berry M. N. et al. (1989): Clin. Chem. 35,817.

24. Henry R.J. et al. (1974): Clin. Chem., Harper \& Row New York, Sec. Edit. 643.

25. Ohkawa H, Ohishi N, Yagi K. (1979): Assay for lipid peroxides in animal tissues by thio barbituric acid reaction Anal. Biochem.95:358.

26. Kakkar P, Das B, Viswanathan P.N. (1984): Amodified spectrophotometric assay of superoxide dismutase. Indian $\mathrm{J}$ Biochem Biophys 2:130-132.

27. Sinha AK. (1972): Colorimetric assay of catalase. Analytical Biochem. , 47: 389.

28. Singh N.P, McCoy M.T, Tice R.R, Schneider E.L. (1988): A simple technique for quantitation of low levels of DNA damage in individual cells Exp Cell Res 175(1): 184-191.

29. Suvarna Kim S, Christopher Layton, Bancroft John D. (2013): Bancroft's Theory and Practice of Histological Techniques, 7th Edition.

30. Levesque, R. SPSS Programming and Data Management: Guide for SPSS and SAS Users, 4th ed., SPSS Inc., Chicago. IL.2007; 606066412.

31. Yang Y, Qina Z, Zenga W, et al. (2017): Toxicity assessment of nanoparticles in various systems and organs . Nanotechnol. Rev. 6(3): 279-289.

32. Shakeel M, Jabeen F, Shabbir S, et al. (2016): Toxicity of nanotitanium dioxide $\left(\mathrm{TiO}_{2}-\mathrm{NP}\right)$ through various routes of exposure: a review. Biol. Trace Elem. Res. 172(1):1- 36.

33. Grande F and Tucci P. (2016): Titanium dioxide nanoparticles: a risk for human health? Mini Rev. Med. Chem. 16(9):762- 769.

34. Sadauskas E, Wallin H, Stoltenberg $\mathbf{M}$, Vogel U, Doering P, et al. (2007): Kupffer cells are central in the removal of nanoparticles from the organism Part Fibre Toxicol 4: 10.

35. Valentini X, Rugira P, Frau A, Tagliatti V, Conotte R, Laurent S, Colet JM and Nonclercq D (2019): Hepatic and Renal Toxicity Induced by $\mathrm{TiO} 2$ Nanoparticles in Rats: A Morphological and Metabonomic Study. Journal of Toxicology. 1-19.

36. Duan Y, Liu J, Ma L, Li N, Liu $H$, Wang J, Zheng L, Liu C, Wang $X$, Zhao X, Yan J, Wang S, Wang $H$, Zhang $X$, Hong $F$. (2010): Toxicological characteristics of nanoparticulate anatase titanium dioxide in mice Biomaterials 31(5): 894-899.

37. Jia X, Wang S, Zhou L, Sun L. (2017): The Potential Liver, Brain, and Embryo Toxicity of Titanium Dioxide Nanoparticles on Mice, DOI 10.1186/s11671017-2242-2.

38. Anbu S, Saravanan N. (2013): Beneficial Effect of Morin on Lipid Peroxidation and Antioxidant Status in Rats with Ethanol Induced Dyslipidemia and Liver Injury. International 
Journal of Pharmaceutical \& Biological Archives 2013; 4(1): 208-217.

39. Bhakuni G.H, Bedi O, Bariwal J, Kumar P. (2017): Hepatoprotective Activity of Morin and its Semi-Synthetic Derivatives Against Alcohol Induced Hepatotoxicity in Rats, Indian J Physiol Pharmacol 2017; 61(2) J Physiol Pharmacol 2017; 61(2) : 175-190.

40. Khan R.A, Khan M.R, Sahreen S. (2012): Protective effects of rutin against potassium bromate induced nephrotoxicity in rats. http://www.biomedcentral.com/1 472-6882/12/204.

41. Canli E.G, Canli M. (2017): Effects of aluminum, copper, and titanium nanoparticles on some blood parameters in Wistar rats. Turk J Zool 41: 259-266 C TÜBİTAK doi: 10.3906/zoo1512-23.

42. Khattab H.A.H. (2012): Effect of Morin against GentamicinInduced Nephrotoxicity in Young Male Rats. The Egyptian Journal of Hospital Medicine, Vol., 49: 705- 717.

43. Parabathina R.K, Muralinath E, Swamy P.L, Krishna V.V.S.N.H, Sree K.S. (2011): Role of certain flavonoids and vitamin-E against doxorubicininduced oxidative stress. J. Chem. Pharm. Res, 3(2):816-834.

44. Moradi A, Ziamajidi $\mathrm{N}$, Ghafourikhosroshahi

A, Abbasalipourkabir R. (2019): Effects of vitamin A and vitamin $E$ on attenuation of titanium dioxide nanoparticles-induced toxicity in the liver of male Wistar rats. Mol Biol Rep. 46(3):2919-2932.
45. Mahboob S, Al-Ghanim K.A, Al-Mulhim N.M.A. (2017): Fish exposure to sub-lethal toxicity of nano-titanium oxide and changes in muscular antioxidant enzymes and protective role of vitamins c and $\mathrm{e}$ in Clarias gariepinus. Int. J. Agric. Biol., 19: 1505-1510.

46. Magalingam K.B, Radhakrishnan Haleagrahara N. (2013): Rutin, a bioflavonoid antioxidant protects rat pheochromocytoma (pc-12) cells against 6hydroxydopamine (6-ohda)induced neurotoxicity. international journal of molecular medicine 32: 235-240.

47. Santonastaso M, Mottola F, Colacurci N, Iovine C, Pacifico, S, Cammarota M, Cesaroni F, Rocco L. (2019): In vitro genotoxic effects of titanium dioxide nanoparticles (nTiO2) in human sperm cells. Mol Reprod Dev.,1-9.

48. Liu W, Yang Y.S, Zhou Q, Xie L, Li P \& Sun T. (2007): Impact assessment of cadmium contamination on rice (Oryza sativa L.) seedlings at molecular and population levels using multiple biomarkers. Chemosphere, 67, 1155-1163..

49. Bhattacharya K, Davoren M, Boertz J, Schins Rp, Hoffmann E, Dopp E. (2009): Titanium dioxide nanoparticles induce oxidative stress and DNA-adduct formation but not DNA-breakage in human lung cells. Part Fibre Toxicol 21: 6-17. 
50. Hackenberg S, Friehs G, Froelich K, Ginzkey C, Koehler C, Scherzed A, Burghartz M, Hagen R, Kleinsasser N. (2010): Intracellular distribution, genoand cytotoxic effects of nanosized titanium dioxide particles in the anatase crystal phase on human nasal mucosa cells. Toxicol Lett 195:9-14.

\section{Warheit D.B, Hoke R.A, Finlay} C, Donner E.M, Reed K.L, Sayes C.M. (2007): Development of a base of toxicity tests using ultrafineTiO2 particles as a component of nanoparticle risk management. ToxicolLett. 171: 99-110.
52. Chen J, Dong X, Zhao J, Tang G. (2009): In vivo acute toxicity of titanium dioxide nanoparticles to mice after intraperitioneal injection, (www.interscience.wiley.com) DOI 10.1002/jat.1414.

53. Ashraf J, Nagma , Siddique J, Mirani N, Rub A. (2012): Protective effect of rutin against carbon tetrachloride-induced hepatotoxicity in mice. International Journal of Drug Development \& Research, Vol. 4 Issue 2 | ISSN 0975-9344. 
Table 1: Effect of $\mathrm{TiO}_{2}$ NPs administration on serum liver functions test and possible protective effect of morin and/or rutin.

\begin{tabular}{|c|c|c|c|c|c|c|c|c|}
\hline Group & & $\begin{array}{l}\text { ALT } \\
(\mathbf{U} / \mathbf{L})\end{array}$ & $\begin{array}{l}\text { AST } \\
\text { (U/L) }\end{array}$ & $\begin{array}{l}\text { ALP } \\
\text { (U/L) }\end{array}$ & $\begin{array}{l}\text { Total } \\
\text { Protein(g/ } \\
\text { dl) }\end{array}$ & $\begin{array}{l}\text { Albumin( } \\
\text { g/dl) }\end{array}$ & $\begin{array}{l}\text { total } \\
\text { Bilirubin } \\
(\mathrm{mg} / \mathrm{dl}) \\
\end{array}$ & $\begin{array}{l}\text { direct } \\
\text { Bilirubin } \\
(\mathrm{mg} / \mathrm{dl}) \\
\end{array}$ \\
\hline $\begin{array}{l}\text { G1 } \\
\text { (negative } \\
\text { control) }\end{array}$ & $\begin{array}{l}\text { mean } \pm \\
\text { SEM }\end{array}$ & $\begin{array}{c}16.12 \\
\pm 0.70^{\mathrm{e}}\end{array}$ & $\begin{array}{c}16.75 \\
\pm 1.29^{\mathrm{d}}\end{array}$ & $\begin{array}{l}183.12 \\
\pm 5.46^{\mathrm{d}}\end{array}$ & $\begin{array}{c}7.05 \\
\pm .064^{\mathrm{ab}}\end{array}$ & $\begin{array}{l}4.15 \\
\pm 0.11^{\mathrm{a}}\end{array}$ & $0.76 \pm 0.48^{c}$ & $0.13 \pm 0.19^{\mathrm{c}}$ \\
\hline \multirow[t]{3}{*}{$\begin{array}{l}\text { G2 } \\
\text { (Morin) }\end{array}$} & $\begin{array}{l}\text { mean } \pm \\
\text { SEM }\end{array}$ & $\begin{array}{c}25.82 \\
\pm 1.20^{\mathrm{c}}\end{array}$ & $\begin{array}{c}23.95 \\
\pm 1.73^{\mathrm{cd}}\end{array}$ & $\begin{array}{l}191.15 \\
\pm 7.9^{\mathrm{cd}}\end{array}$ & $\begin{array}{c}7.32 \\
\pm 0.179^{\mathrm{a}}\end{array}$ & $\begin{array}{c}4.10 \\
\pm 0.15^{\mathrm{ab}}\end{array}$ & $0.57 \pm 0.40^{c}$ & $0.11 \pm 0.19^{\mathrm{c}}$ \\
\hline & $* \%$ & 60.17 & 42.90 & 4.38 & 3.82 & -1.20 & -25.0 & -15.38 \\
\hline & $* * \%$ & -72.96 & -76.74 & -51.23 & 45.81 & 59.53 & -80.13 & -80.0 \\
\hline \multirow[t]{3}{*}{ G3 (Rutin) } & $\begin{array}{l}\text { mean } \pm \\
\text { SEM }\end{array}$ & $\begin{array}{c}25.00 \\
\pm 0.67^{\mathrm{cd}}\end{array}$ & $\begin{array}{l}25.02 \\
\pm 2.00^{\mathrm{c}}\end{array}$ & $\begin{array}{l}210.32 \\
\pm 5.00^{c}\end{array}$ & $\begin{array}{c}6.97 \\
\pm 0.085^{\mathrm{ab}}\end{array}$ & $\begin{array}{c}4.22 \\
\pm 0.16^{\mathrm{a}}\end{array}$ & $0.67 \pm 0.54^{c}$ & $0.13 \pm 0.23^{c}$ \\
\hline & $* \%$ & 55.08 & 49.37 & 14.85 & -1.13 & 1.68 & -11.84 & 0 \\
\hline & $* * \%$ & -73.82 & -75.70 & -46.34 & 38.84 & 64.20 & -76.65 & -76.36 \\
\hline \multirow[t]{2}{*}{$\begin{array}{l}\text { G4 } \\
\left(\mathrm{TiO}_{2} \mathrm{NPs}\right)\end{array}$} & $\begin{array}{l}\text { mean } \pm \\
\text { SEM }\end{array}$ & $\begin{array}{l}95.50 \\
\pm 2.52^{\mathrm{a}}\end{array}$ & $\begin{array}{l}102.97 \\
\pm 2.39^{\mathrm{a}}\end{array}$ & $\begin{array}{l}392.00 \\
\pm 7.17^{\mathrm{a}}\end{array}$ & $\begin{array}{c}5.02 \\
\pm 0.217^{d}\end{array}$ & $\begin{array}{c}2.57 \\
\pm 0.085^{\mathrm{d}}\end{array}$ & $2.87 \pm 2.28^{\mathrm{a}}$ & $0.55 \pm 0.27^{\mathrm{a}}$ \\
\hline & $* \%$ & 492.43 & 514.70 & 114.06 & -28.79 & -38.07 & 277.63 & 323.07 \\
\hline \multirow{3}{*}{$\begin{array}{l}\text { G5 } \\
\text { (TiO } \\
\text { NPs+ } \\
\text { Morin) }\end{array}$} & $\begin{array}{l}\text { mean } \pm \\
\text { SEM }\end{array}$ & $\begin{array}{c}40.82 \\
\pm 1.26^{\mathrm{b}}\end{array}$ & $\begin{array}{c}37.62 \\
\pm 1.16^{\mathrm{b}}\end{array}$ & $\begin{array}{l}277.10 \\
\pm 1.85^{\mathrm{b}}\end{array}$ & $\begin{array}{c}6.17 \\
\pm 0.085^{c}\end{array}$ & $\begin{array}{c}3.40 \\
\pm 0.040^{c}\end{array}$ & $1.36 \pm 1.19^{b}$ & $0.28 \pm 0.17^{\mathrm{b}}$ \\
\hline & $* \%$ & 153.22 & 124.59 & 51.32 & -12.48 & -18.07 & 78.94 & 115.38 \\
\hline & $* * \%$ & -57.25 & -63.46 & -29.31 & 22.90 & 32.29 & -52.61 & -49.09 \\
\hline \multirow{3}{*}{$\begin{array}{l}\text { G6 } \\
\text { (TiO } \\
\text { NPs+ } \\
\text { Rutin) }\end{array}$} & $\begin{array}{l}\text { mean } \pm \\
\text { SEM }\end{array}$ & $\begin{array}{c}42.00 \\
\pm 1.28^{\mathrm{b}}\end{array}$ & $\begin{array}{c}39.62 \\
\pm 1.22^{\mathrm{b}}\end{array}$ & $\begin{array}{l}274.40 \\
\pm 2.28^{\mathrm{b}}\end{array}$ & $\begin{array}{c}6.65 \\
\pm 0.064^{\mathrm{bc}}\end{array}$ & $\begin{array}{c}3.65 \\
\pm 0.64^{b c}\end{array}$ & $1.26 \pm 1.16^{\mathrm{b}}$ & $0.25 \pm 0.13^{b}$ \\
\hline & $* \%$ & 160.54 & 136.53 & 49.84 & -5.67 & -12.04 & 65.78 & 92.30 \\
\hline & $* * \%$ & -56.02 & -61.32 & -30.00 & 32.47 & 42.02 & -56.09 & -54.54 \\
\hline \multirow{3}{*}{$\begin{array}{l}\text { G7 } \\
\text { (TiO2 } \\
\text { NPs+ } \\
\text { Morin+ } \\
\text { Rutin) }\end{array}$} & $\begin{array}{l}\text { mean } \pm \\
\text { SEM }\end{array}$ & $\begin{array}{c}19.07 \\
\pm 0.79^{\text {de }}\end{array}$ & $\begin{array}{c}19.10 \\
\pm 1.42^{\mathrm{cd}}\end{array}$ & $\begin{array}{l}183.80 \\
\pm 2.83^{\mathrm{d}}\end{array}$ & $\begin{array}{c}7.27 \\
\pm 0.149^{b}\end{array}$ & $\begin{array}{c}4.12 \\
\pm 0.85^{\mathrm{ab}}\end{array}$ & $0.68 \pm 0.49^{c}$ & $0.14 \pm 0.18^{c}$ \\
\hline & $* \%$ & 18.30 & 14.02 & 0.37 & 3.12 & -0.72 & -10.52 & 7.64 \\
\hline & $* * \%$ & -80.03 & -81.45 & -53.11 & 44.82 & 60.31 & -76.30 & -74.54 \\
\hline
\end{tabular}

a, b, c, d, e: Superscripts to be compared statistically within the same column, $* \%$ mean Percentage change/ Control and $* * \%$ that mean Percentage change/ toxic group. Values with different letter superscripts are significantly different $(p<0.05)$. 
Table 2: Effect of $\mathrm{TiO}_{2}$ NPs administration on serum minerals and possible protective effect of morin and/or rutin.

\begin{tabular}{|c|c|c|c|c|c|}
\hline Group & & $\begin{array}{l}\text { Calcium } \\
(\mathrm{Ca}) \\
(\mathrm{mg} / \mathrm{dl}) \\
\end{array}$ & $\begin{array}{l}\text { Potassium } \\
(\mathrm{mmol} / \mathrm{L})\end{array}$ & $\begin{array}{l}\text { Sodium (Na) } \\
(\mathrm{mmol} / \mathrm{L})\end{array}$ & $\begin{array}{l}\text { phosphorous } \\
\text { (P) } \\
(\mathrm{mg} / \mathrm{dl})\end{array}$ \\
\hline $\begin{array}{l}\text { G1 (negative } \\
\text { control) }\end{array}$ & mean $\pm \mathrm{SEM}$ & $\begin{array}{c}9.32 \\
\pm 0.15^{\mathrm{a}}\end{array}$ & $\begin{array}{c}5.75 \\
\pm 0.06^{\mathrm{c}}\end{array}$ & $\begin{array}{l}137.32 \\
\pm 0.46^{\mathrm{ab}}\end{array}$ & $\begin{array}{c}4.05 \\
\pm 0.23^{\mathrm{b}}\end{array}$ \\
\hline \multirow[t]{3}{*}{ G2 (Morin) } & mean \pm SEM & $\begin{array}{c}9.12 \\
\pm 0.20^{\mathrm{ab}}\end{array}$ & $\begin{array}{c}3.90 \\
\pm 0.15^{\mathrm{c}}\end{array}$ & $\begin{array}{l}140.10 \\
\pm 0.88^{\mathrm{a}}\end{array}$ & $\begin{array}{c} \\
4.30 \\
\pm 0.19^{\mathrm{b}}\end{array}$ \\
\hline & $* \%$ & -2.14 & -32.17 & 2.02 & 6.17 \\
\hline & $* * \%$ & 44.76 & -35.00 & 14.83 & -46.38 \\
\hline \multirow[t]{3}{*}{$\begin{array}{l}\text { G3 } \\
\text { (Rutin) }\end{array}$} & mean \pm SEM & $\begin{array}{c}9.05 \\
\pm 0.15^{\mathrm{ab}}\end{array}$ & $\begin{array}{c}4.12 \\
\pm 0.18^{\mathrm{c}}\end{array}$ & $\begin{array}{l}139.55 \\
\pm 1.53^{\mathrm{a}}\end{array}$ & $\begin{array}{c}4.12 \\
\pm 0.20^{\mathrm{b}}\end{array}$ \\
\hline & $* \%$ & -2.89 & -28.34 & 1.62 & 1.72 \\
\hline & $* * \%$ & 43.65 & -31.33 & 14.38 & -48.62 \\
\hline \multirow[t]{2}{*}{$\begin{array}{l}\text { G4 } \\
\left(\mathrm{TiO}_{2} \mathrm{NPs}\right)\end{array}$} & mean $\pm \mathrm{SEM}$ & $\begin{array}{c}6.30 \\
\pm 0.18^{\mathrm{c}} \\
\end{array}$ & $\begin{array}{c}6.00 \\
\pm 0.09^{\mathrm{a}} \\
\end{array}$ & $\begin{array}{c}122.0 \\
\pm 2.95^{\mathrm{c}} \\
\end{array}$ & $\begin{array}{c}8.02 \\
\pm 0.59^{\mathrm{a}} \\
\end{array}$ \\
\hline & $* \%$ & -32.40 & 4.34 & -11.15 & 98.02 \\
\hline \multirow{3}{*}{$\begin{array}{l}\text { G5 } \\
\left(\mathrm{TiO}_{2} \mathrm{NPs}^{+}\right. \\
\text {Morin) }\end{array}$} & mean \pm SEM & $\begin{array}{c}8.45 \\
\pm 0.06^{\mathrm{b}}\end{array}$ & $\begin{array}{c}4.97 \\
\pm 0.08^{\mathrm{b}}\end{array}$ & $\begin{array}{l}132.45 \\
\pm 0.89^{\mathrm{b}}\end{array}$ & $\begin{array}{c}5.32 \\
\pm 0.17^{\mathrm{b}}\end{array}$ \\
\hline & $* \%$ & -9.33 & -13.56 & -3.54 & 31.35 \\
\hline & $* * \%$ & 34.12 & -17.16 & 8.56 & -33.66 \\
\hline \multirow{3}{*}{$\begin{array}{l}\text { G6 } \\
\text { (TiO } 2 \mathrm{NPs}^{+} \\
\text {Rutin) }\end{array}$} & mean $\pm \mathrm{SEM}$ & $\begin{array}{c}8.47 \\
\pm 0.09^{\mathrm{b}}\end{array}$ & $\begin{array}{c}5.05 \\
\pm 0.10^{\mathrm{b}}\end{array}$ & $\begin{array}{l}134.75 \\
\pm 0.55^{\mathrm{ab}} \\
\end{array}$ & $\begin{array}{c}4.97 \\
\pm 0.32^{\mathrm{b}}\end{array}$ \\
\hline & $* \%$ & -9.12 & -12.17 & -1.87 & 22.71 \\
\hline & $* * \%$ & 34.44 & -15.83 & 10.45 & -38.02 \\
\hline \multirow{3}{*}{$\begin{array}{l}\text { G7 } \\
\left(\mathrm{TiO}_{2} \mathrm{NPs}+\right. \\
\text { Morin+ } \\
\text { Rutin) }\end{array}$} & mean $\pm \mathrm{SEM}$ & $\begin{array}{c}9.52 \\
\pm 0.18^{\mathrm{a}} \\
\end{array}$ & $\begin{array}{r}3.87 \\
\pm 0.08^{\mathrm{c}} \\
\end{array}$ & $\begin{array}{r}139.9 \\
\pm 0.50^{\mathrm{a}} \\
\end{array}$ & $\begin{array}{c}4.07 \\
\pm 0.19^{\mathrm{b}} \\
\end{array}$ \\
\hline & $* \%$ & 2.14 & -32.69 & 1.87 & 0.49 \\
\hline & $* * \%$ & 51.11 & -35.5 & 14.67 & -49.25 \\
\hline
\end{tabular}

a, b, c, d, e: Superscripts to be compared statistically within the same column, *\% mean Percentage change/ Control and $* * \%$ that mean Percentage change/ toxic group. Values with different letter superscripts are significantly different $(\mathrm{p}<0.05)$. 
Table 3: Effect of $\mathrm{TiO}_{2}$ NPs administration on hepatic tissue of antioxidant and possible protective effect of morin and/or rutin.

\begin{tabular}{|c|c|c|c|c|c|}
\hline Group & & $\begin{array}{l}\text { MDA (umol/g } \\
\text { tissue) }\end{array}$ & $\begin{array}{l}\text { SOD }(u / g \\
\text { tissue) }\end{array}$ & $\begin{array}{l}\mathrm{CAT} \text { (Umol } \\
\mathrm{H}_{2} \mathrm{O}_{2} / \mathrm{g} \text { tissue) }\end{array}$ & $\begin{array}{l}\text { GSH }(\mathrm{mg} / \mathrm{g} \\
\text { tissue) }\end{array}$ \\
\hline $\begin{array}{l}\text { G1 (negative } \\
\text { control) }\end{array}$ & $\begin{array}{c}\text { mean } \pm \\
\text { SEM }\end{array}$ & $\begin{array}{c}31.08 \\
\pm 5.54^{\mathrm{b}} \\
\end{array}$ & $54.15 \pm 3.45^{\mathrm{a}}$ & $78.08 \pm 4.92^{\mathrm{a}}$ & $94.15 \pm 7.61^{\mathrm{a}}$ \\
\hline \multirow[t]{3}{*}{ G2 (Morin) } & $\begin{array}{l}\text { mean } \pm \\
\text { SEM }\end{array}$ & $60.38 \pm 8.12^{b}$ & $50.77 \pm 5.60^{a}$ & $70.18 \pm 4.18^{\mathrm{ab}}$ & $105.20 \pm 17.61^{\mathrm{a}}$ \\
\hline & $* \%$ & 94.27 & -6.24 & -10.11 & 11.73 \\
\hline & $* * \%$ & -66.40 & 248.93 & 214.99 & 511.62 \\
\hline \multirow[t]{3}{*}{$\begin{array}{l}\text { G3 } \\
\text { (Rutin) }\end{array}$} & $\begin{array}{l}\text { mean } \pm \\
\text { SEM }\end{array}$ & $33.63 \pm 6.35^{b}$ & $53.97 \pm 4.88^{\mathrm{a}}$ & $60.90 \pm 6.50^{\mathrm{ab}}$ & $87.48 \pm 5.94^{\mathrm{a}}$ \\
\hline & $* \%$ & 8.20 & -0.33 & -22.00 & -7.08 \\
\hline & $* * \%$ & -81.28 & 270.92 & 173.33 & 408.60 \\
\hline \multirow[t]{2}{*}{$\begin{array}{l}\text { G4 } \\
\left(\mathrm{TiO}_{2} \mathrm{NPs}\right)\end{array}$} & $\begin{array}{l}\text { mean } \pm \\
\text { SEM }\end{array}$ & $179.72 \pm 18.42^{\mathrm{a}}$ & $14.55 \pm 3.02^{b}$ & $22.28 \pm 1.58^{c}$ & $17.20 \pm 2.87^{b}$ \\
\hline & $* \%$ & 478.24 & -73.13 & -71.46 & -81.73 \\
\hline \multirow{3}{*}{$\begin{array}{l}\text { G5 } \\
\text { ( } \mathrm{TiO}_{2} \mathrm{NPs}+ \\
\text { Morin) }\end{array}$} & $\begin{array}{l}\text { mean } \pm \\
\text { SEM }\end{array}$ & $68.86 \pm 5.20^{b}$ & $52.52 \pm 5.84^{\mathrm{a}}$ & $67.30 \pm 4.66^{\mathrm{ab}}$ & $99.17 \pm 14.36^{\mathrm{a}}$ \\
\hline & $* \%$ & 121.55 & -3.01 & -13.80 & 5.33 \\
\hline & $* * \%$ & -61.68 & 260.96 & 202.06 & 476.56 \\
\hline \multirow{3}{*}{$\begin{array}{l}\text { G6 } \\
\text { ( } \mathrm{TiO}_{2} \mathrm{NPs}+ \\
\text { Rutin) }\end{array}$} & $\begin{array}{l}\text { mean } \pm \\
\text { SEM }\end{array}$ & $51.04 \pm 10.74^{b}$ & $55.05 \pm 4.63^{\mathrm{a}}$ & $55.07 \pm 4.56^{b}$ & $85.02 \pm 5.80^{\mathrm{a}}$ \\
\hline & $* \%$ & 64.22 & 1.66 & -29.46 & -9.69 \\
\hline & $* * \%$ & -71.60 & 278.35 & 147.17 & 394.30 \\
\hline \multirow{3}{*}{$\begin{array}{l}\text { G7 } \\
\left(\mathrm{TiO}_{2} \mathrm{NPs}^{+}\right. \\
\text {Morin+ } \\
\text { Rutin) }\end{array}$} & $\begin{array}{c}\text { mean } \pm \\
\text { SEM }\end{array}$ & $32.79 \pm 3.37^{b}$ & $51.55 \pm 1.53^{\mathrm{a}}$ & $78.77 \pm 5.03^{\mathrm{a}}$ & $94.82 \pm 6.87^{\mathrm{a}}$ \\
\hline & $* \%$ & 5.50 & -4.80 & 0.88 & 0.71 \\
\hline & $* * \%$ & -81.75 & 254.29 & 254.54 & 451.27 \\
\hline
\end{tabular}

a, b, c, d, e: Superscripts to be compared statistically within the same column, *\% mean Percentage change/ Control and $* * \%$ that mean Percentage change/ toxic group. Values with different letter superscripts are significantly different $(p<0.05)$. 
Table 4: Effect of $\mathrm{TiO}_{2}$ NPs administration on DNA fragmentation hepatic tissue and protective effect of morin and/or rutin.

\begin{tabular}{|c|c|c|c|c|c|}
\hline Group & & $\begin{array}{l}\text { Comet } \\
\%\end{array}$ & $\begin{array}{l}\text { Tail length } \\
\text { (px) }\end{array}$ & $\begin{array}{l}\text { DNA } \\
\text { Tail } \\
\%\end{array}$ & $\begin{array}{l}\text { Tail } \\
\text { moment } \\
\text { (arbitrary } \\
\text { unit) }\end{array}$ \\
\hline $\begin{array}{l}\text { G1 (negative } \\
\text { control) }\end{array}$ & mean $\pm \mathrm{SEM}$ & $\begin{array}{l}16.00 \\
\pm 0.83^{b c}\end{array}$ & $8.13 \pm 0.52^{b}$ & $8.15 \pm 0.62^{b}$ & $\begin{array}{l}0.58 \\
\pm 0.047^{\mathrm{b}}\end{array}$ \\
\hline \multirow[t]{3}{*}{ G2 (Morin) } & mean $\pm \mathrm{SEM}$ & $\begin{array}{l}13.90 \\
\pm 0.53^{\mathrm{c}}\end{array}$ & $6.65 \pm 0.66^{b}$ & $7.60 \pm 0.81^{b}$ & $\begin{array}{l}0.48 \\
\pm 0.047^{b}\end{array}$ \\
\hline & $* \%$ & -13.12 & -18.20 & -6.74 & -17.24 \\
\hline & $* * \%$ & -39.08 & -45.71 & -39.29 & -94.33 \\
\hline \multirow[t]{3}{*}{$\begin{array}{l}\text { G3 } \\
\text { (Rutin) }\end{array}$} & mean \pm SEM & $\begin{array}{l}16.95 \\
\pm 0.83^{\mathrm{bc}}\end{array}$ & $6.37 \pm 0.35^{b}$ & $6.95 \pm 0.45^{b}$ & $\begin{array}{l}0.60 \\
\pm 0.040^{\mathrm{b}}\end{array}$ \\
\hline & $* \%$ & 5.93 & -21.64 & -14.72 & 3.44 \\
\hline & $* * \%$ & -25.72 & -48.00 & -44.48 & -92.91 \\
\hline \multirow[t]{2}{*}{$\begin{array}{l}\text { G4 } \\
\left(\mathrm{TiO}_{2} \mathrm{NPs}\right)\end{array}$} & mean $\pm \mathrm{SEM}$ & $\begin{array}{l}22.82 \\
\pm 1.15^{\mathrm{a}}\end{array}$ & $\begin{array}{l}12.25 \\
\pm 0.85^{\mathrm{a}}\end{array}$ & $\begin{array}{l}12.52 \\
\pm 1.05^{\mathrm{a}}\end{array}$ & $8.47 \pm 2.56^{\mathrm{a}}$ \\
\hline & $* \%$ & 42.62 & 50.67 & 53.61 & 1360.34 \\
\hline \multirow{3}{*}{$\begin{array}{l}\text { G5 } \\
\left(\mathrm{TiO}_{2} \mathrm{NPs}+\right. \\
\text { Morin) }\end{array}$} & mean $\pm \mathrm{SEM}$ & $\begin{array}{l}16.77 \\
\pm 0.57^{\mathrm{bc}}\end{array}$ & $7.82 \pm 0.54^{b}$ & $8.30 \pm 0.71^{b}$ & $\begin{array}{l}0.70 \\
\pm 0.040^{b}\end{array}$ \\
\hline & $* \%$ & 4.81 & -3.81 & 1.84 & 20.68 \\
\hline & $* \mathrm{P}$ & -26.51 & -36.16 & -33.70 & -91.73 \\
\hline \multirow{3}{*}{$\begin{array}{l}\text { G6 } \\
\text { (TiO) } \mathrm{NPs}^{+} \\
\text {Rutin) }\end{array}$} & mean $\pm \mathrm{SEM}$ & $\begin{array}{l}18.32 \\
\pm 0.88^{\mathrm{b}}\end{array}$ & $\begin{array}{l}7.70 \\
\pm 0.42^{\mathrm{b}}\end{array}$ & $7.20 \pm 0.30^{b}$ & $\begin{array}{l}0.70 \\
\pm 0.040^{b}\end{array}$ \\
\hline & $* \%$ & 14.50 & -5.28 & -11.65 & 20.68 \\
\hline & $* * \%$ & -19.71 & -37.14 & -42.49 & -91.73 \\
\hline \multirow{3}{*}{$\begin{array}{l}\text { G7 } \\
\text { (TiO }{ }_{2} N^{+}+ \\
\text {Morin+ } \\
\text { Rutin) }\end{array}$} & mean $\pm \mathrm{SEM}$ & $\begin{array}{l}16.10 \\
\pm 0.69^{\mathrm{bc}}\end{array}$ & $7.82 \pm 0.69^{b}$ & $8.40 \pm 0.52^{b}$ & $\begin{array}{l}0.55 \\
\pm 0.064^{b}\end{array}$ \\
\hline & $* \%$ & 0.62 & -3.81 & 3.06 & -5.17 \\
\hline & $* * \%$ & -29.44 & -36.16 & -32.90 & -93.50 \\
\hline
\end{tabular}

a, b, c, d, e: Superscripts to be compared statistically within the same column, $* \%$ mean Percentage change/ Control and $* * \%$ that mean Percentage change/ toxic group. Values with different letter superscripts are significantly different $(p<0.05)$. 

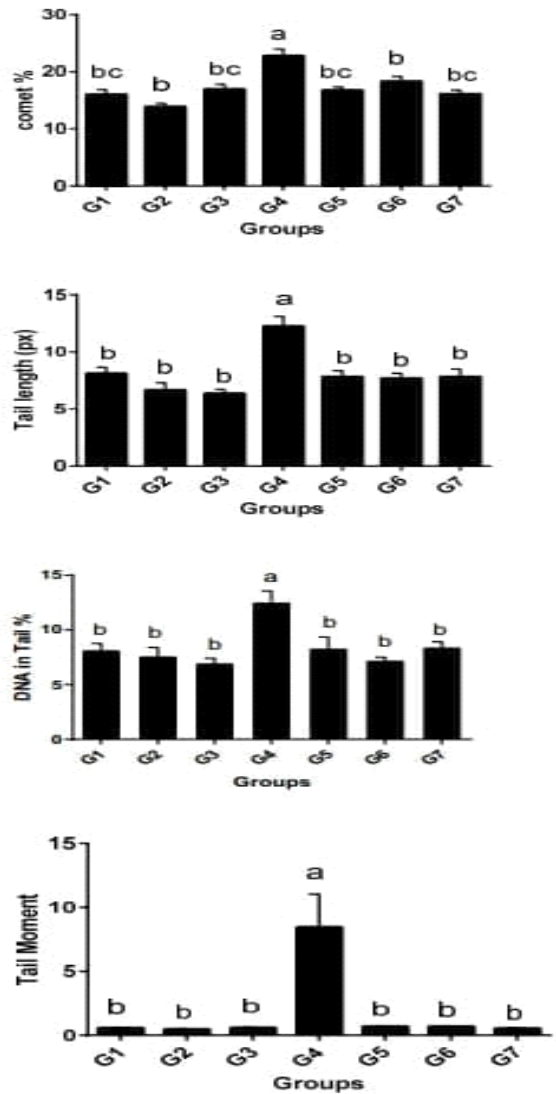

Figures 1: Effect of morin and/ or rutin administration on comet assay parameters in liver tissue of $\mathrm{TiO}_{2}$ NPs intoxicated rats. 


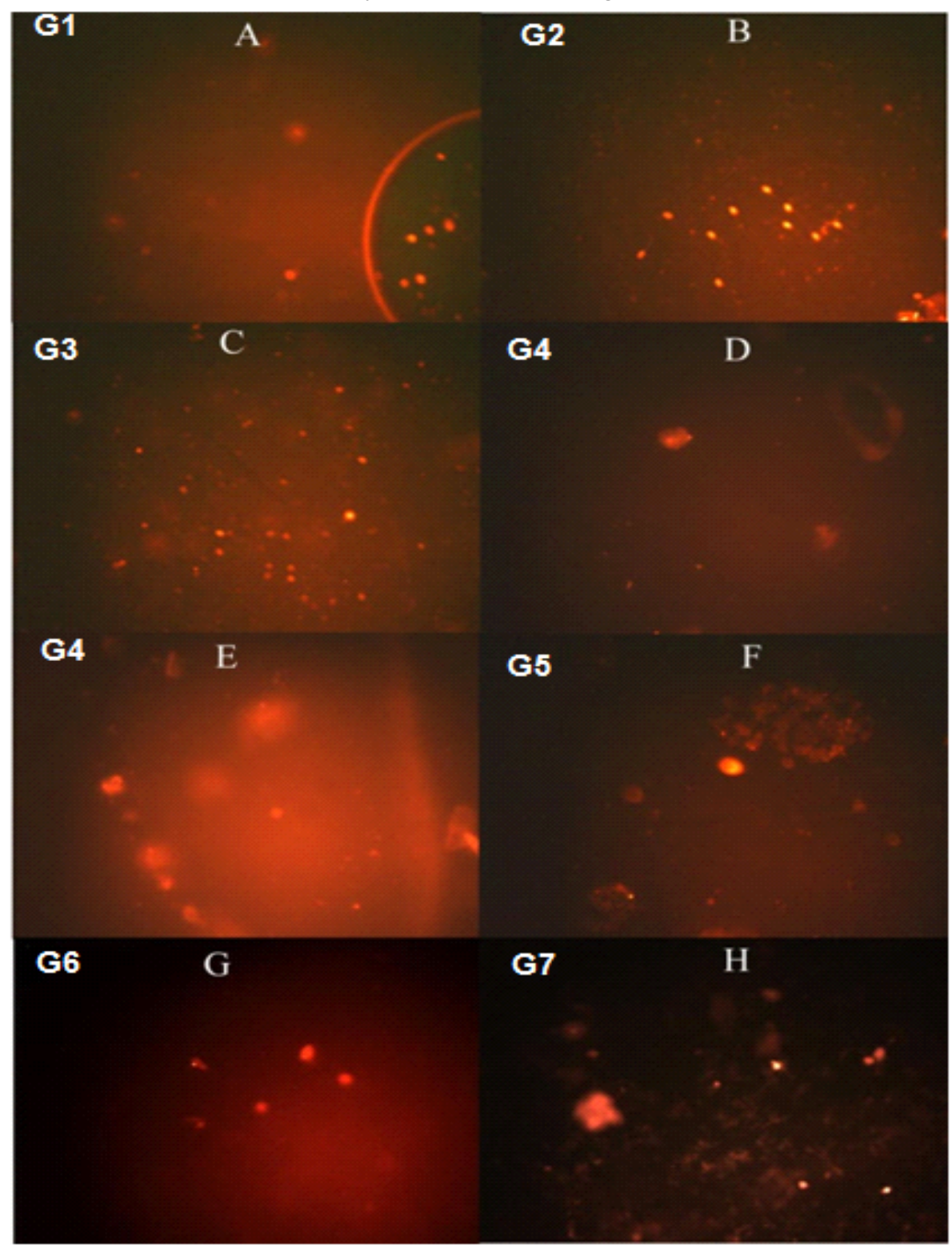

Figure 2: Photomicrographs representation of liver DNA damage, using comet assay indifferent animal groups; A, Group1 (control); B, Group2 (morin); C, Group3 (rutin); D and E, Group4 ( $\left.\mathrm{TiO}_{2} \mathrm{NPs}\right)$; F, Group5 ( $\mathrm{TiO}_{2} \mathrm{NPs}+$ morin); G, Group6 ( $\mathrm{TiO}_{2}$ NPs+ rutin); H, Group7 ( $\mathrm{TiO}_{2} \mathrm{NPs}+$ morin+ rutin). 
Sherif et al, 2019

Biochemistry letters, 14(13) 2019, Pages 167-185

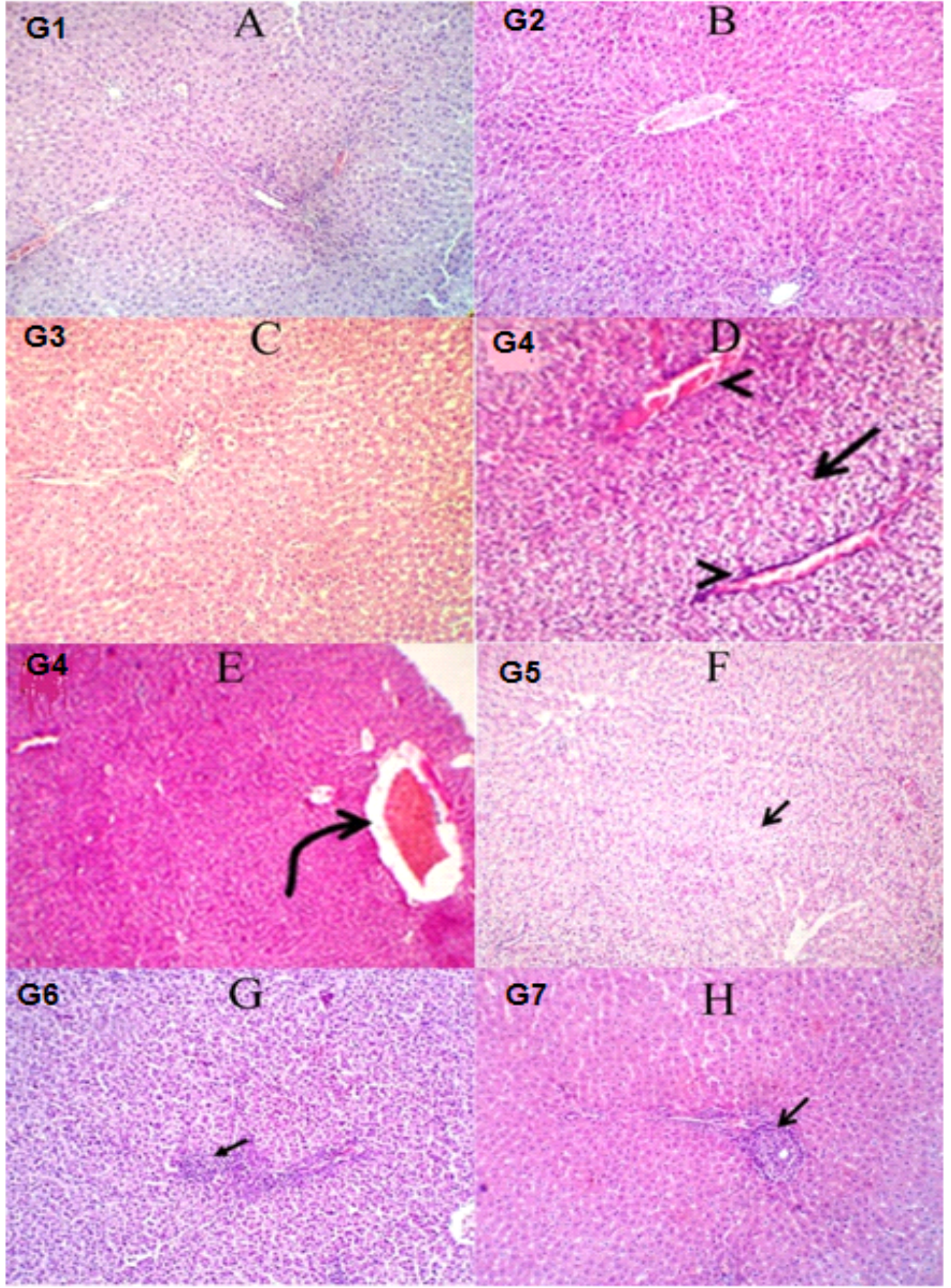

Figure 3. Histopathological examination of liver exposed to TiO2-NPs and coadministrated with morin and rutin during the whole period of experiment. A (G1), B (G2), C (G3), D and E (G4), F (G5), G (G6), and H (G7). H\&E, 300x. 